\title{
IL-17 induces NSCLC A549 cell proliferation via the upregulation of HMGA1, resulting in an increased cyclin D1 expression
}

\author{
CHENHUI ZHAO $^{1}$, YONGTING $\mathrm{LI}^{2}$, WEIMING ZHANG ${ }^{3}$, DAN ZHAO $^{2}$, LING MA ${ }^{1}$, PEI MA $^{1}$, \\ FENGMING YANG ${ }^{1}$, YINGWEI WANG ${ }^{2}$, YONGQIAN SHU ${ }^{1}$ and WEN QIU ${ }^{2}$ \\ ${ }^{1}$ Department of Oncology, The First Affiliated Hospital of Nanjing Medical University, Nanjing, Jiangsu 210009; \\ ${ }^{2}$ Department of Immunology, Nanjing Medical University, Nanjing, Jiangsu 211166; ${ }^{3}$ Department of Pathology, \\ The First Affiliated Hospital of Nanjing Medical University, Nanjing, Jiangsu 210009, P.R. China
}

Received November 21, 2017; Accepted February 16, 2018

DOI: $10.3892 /$ ijo.2018.4307

\begin{abstract}
Non-small cell lung cancer (NSCLC) is considered to be an inflammation-associated carcinoma. Although interleukin-17 ( $I L-17)$ production contributes to the proliferation and growth of NSCLC, the mechanisms underlying $I L$-17-induced NSCLC cell proliferation have not been fully elucidated. In the present study, by using ELISA and immunohistochemical analyses, we first found that the expression levels of $I L-17, I L-17$ receptor (IL-17R), highmobility group A1 (HMGA1) and cyclin D1 were elevated in the samples of patients with NSCLC. Subsequently, by RT-qPCR, western blot analysis and cell proliferation assay in vitro, we revealed that stimulation with recombinant human $I L-17$ (namely $I L-17 A$ ) markedly induced the expression of HMGAl and cyclin D1 in the A549 cells (a human lung adenocarcinoma cell line) and promoted cell proliferation. Furthermore, luciferase reporter and ChIP assays confirmed that upregulated $H M G A 1$ directly bound to the cyclin Dl gene promoter and activated its transcription. Notably, the response element of $H M G A 1$ binding to the cyclin D1 promoter was disclosed for the first time, at least to the best of our knowledge. Taken together, our findings indicate that the $I L-17 /$ $H M G A 1 /$ cyclin Dl axis plays an important role in NSCLC cell proliferation and may provide new insight into NSCLC pathogenesis and may thus aid in the development of novel therapeutic targets for NSCLC.
\end{abstract}

Correspondence to: Professor Yongqian Shu, Department of Oncology, The First Affiliated Hospital of Nanjing Medical University, 300 Guangzhou Road, Nanjing, Jiangsu 210009, P.R. China

E-mail: shuyqtg@126.com

Professor Wen Qiu, Department of Immunology, Nanjing Medical University, 101 Longmian Avenue, Nanjing, Jiangsu 211166, P.R. China

E-mail: qiuwen@njmu.edu.cn

Key words: non-small cell lung cancer, interleukin 17, high-mobility group A1, cyclin D1, proliferation

\section{Introduction}

Lung cancer, in which non-small cell lung cancer (NSCLC) accounts for approximately $85 \%$ of cases, is the most lethal type of cancer worldwide (1-3). Studies have suggested that NSCLC is an inflammation-associated carcinoma $(3,4)$; however, although the production of pro-inflammatory cytokines or mediators in the NSCLC microenvironment formed by tumor cells, endothelial cells and infiltrating inflammatory cells has been reported (5-7), the roles of these molecules in NSCLC proliferation and growth remain largely obscure.

Interleukin $17(I L-17)$, also known as $I L-17 A$, is a newly identified pro-inflammatory cytokine $(8,9)$. A number of studies have demonstrated that $I L-17$ production can promote cell proliferation and can thus contribute to NSCLC growth and development (10-13). However, the precise mechanisms underlying IL-17-induced NSCLC cell proliferation are extremely complex $(14,15)$, and are not yet fully understood.

As is known, the expression of proliferation-related genes is associated with the activation of certain molecules in diverse signaling pathways, including various transcription factors (14-17). High-mobility group A1 (HMGAl) is a transcription factor which plays a crucial role in regulation of gene expression and biological process $(18,19)$. Emerging evidence has indicated the significant upregulation of HMGAl expression in several malignant types of cancer, such as bladder cancer, thyroid cancer and NSCLC (20-22), and the overexpression of $H M G A l$ has also been shown to positively correlate with the cell proliferation and malignant status of NSCLC $(23,24)$. Reportedly, cyclin D1 is widely overexpressed in certain types of human cancer, and several growth factors, such as epidermal growth factor $(E G F)$ markedly enhance cancer cell proliferation by increasing cyclin Dl expression $(25,26)$. Moreover, transcription factors, such as nuclear factor $(N F)-\kappa B$ can directly bind to the cyclin $D 1$ gene promoter and result in cyclin $D 1$ gene transcription and cell proliferation (26); the activation of the $p 15 /$ cyclin D1 pathway also greatly promotes NSCLC carcinogenesis (27).

The present study demonstrated that the production of IL-17 and the expression levels of $I L-17 R, H M G A I$ and cyclin D1 were significantly elevated in samples of patients with NSCLC. Moreover, positive correlations were also found 
between the expression of $I L-17 R, H M G A 1$ and cyclin DI. Therefore, we wished to determine whether stimulation with $I L-17$ would enhance NSCLC cell proliferation and increase the expression of $H M G A 1$ and cyclin $D 1$ by binding to $I L-17 R$, as well as whether HMGAl triggers cyclin Dl gene transcription. In addition, we aimed to elucidate the mechanisms involved in $I L-17$-induced NSCLC cell proliferation. For this purpose, we performed a series of experiments in order to shed light into these matters.

\section{Materials and methods}

Human specimens. Plasma samples from patients with NSCLC $(n=40)$ and healthy volunteers $(n=40)$ were collected from the First Affiliated Hospital of Nanjing Medical University (Nanjing, China). Patients were eligible if they were diagnosed with NSCLC by biopsy and had not been treated with chemotherapy or radiotherapy prior to sample collection. Patients were excluded if they suffered from any other disease (trauma, infections, allergies, autoimmune diseases or other inflammatory diseases and cancers). Informed consent was obtained from all patients participating in this research prior to the experiment. This study was approved by the Ethics Committee of Nanjing Medical University and conformed to the guidelines outlined by the Declaration of Helsinki. Specifically, venous blood samples were collected into K3EDTA tubes (Greiner Bio-One; Frickenhausen, Germany) and were then fractionated by centrifugation (10 $\mathrm{min}, 3,000 \mathrm{x} \mathrm{g})$. The plasma was aliquoted and stored at $-80^{\circ} \mathrm{C}$ prior to analysis. NSCLC tissue arrays $(n=60$, paired) were provided by the National Engineering Center for BioChips (Shanghai, China).

Cell lines, reagents and antibodies. The human NSCLC cell lines, A549 (Cat. no. CCL-185), H1299 (Cat. no. CRL-5803) and H1975 (Cat. no. CRL-5908) were obtained from the American Type Culture Collection (ATCC, Manassas, VA, USA). The human adenocarcinoma cell lines, PC9 and SPC-A1, were purchased from the European Collection of Authenticated Cell Cultures (ECACC, Cat. no. 90071810) and the Institute of Biochemistry and Cell Biology of the Chinese Academy of Science (Cat. no. TCHu53), respectively. The human bronchial epithelial cell line (16HBE) was supplied by Dr Gruenert (California Pacific Medical Center, San Francisco, CA, USA). Recombinant human $I L-17$ (IL-17A) and anti-rabbit (Cat. no. HAF008) or anti-mouse (Cat. no. HAF007) HRP-conjugated secondary antibodies were provided by $R \& D$ Systems (Minneapolis, $M N$, USA). The anti- $I L-17$ (Cat. no. ab9565), anti- $I L-17 R$ (Cat. no. ab180904), anti-HMGAl (Cat. no. ab129153) and anticyclin D1 (Cat. no. ab134175) antibodies were supplied by Abcam (Cambridge, UK). The DAB substrate kit, BCA assay kit and Lipofectamine 2000 reagent were from Thermo Fisher Scientific (Waltham, MA, USA). The cell counting kit-8 (CCK-8) was supplied by Dojindo Laboratories (Kumamoto, Japan). Crystal violet was from Sigma-Aldrich (St. Louis, MO, USA). The reverse transcription reagent kit, 2X Taq Master Mix and qPCR SYBR-Green master mix were purchased from Vazyme Biotech (Nanjing, China). The X-tremeGENE HP DNA transfection reagent was from Roche Applied Science (Mannheim, Germany). The dual-luciferase reporter assay system kit was obtained from Promega (Madison, WI, USA). The chromatin immunoprecipitation (ChIP) kit was provided by Cell Signaling Technology (Danvers, MA, USA).

Detection by ELISA. The plasma $I L-17$ concentration was measured using an anti- $I L-17 A$ coated ELISA kit (BMS2017; Thermo Fisher Scientific). Briefly, standard, control and plasma samples were added to the $I L-17 A$ antibody coated wells. Meantime, a biotinylated $I L-17 A$ antibody was added, incubating for $2 \mathrm{~h}$ at room temperature. The streptavidin-HRP was then added to all washed wells and incubated for $1 \mathrm{~h}$, followed by washing and TMB substrate incubation for approximately $10 \mathrm{~min}$. Finally, the enzyme reaction was terminated by stop solution (provided with the kit) and the absorbance at $450 \mathrm{~nm}$ (OD 450) of each well was measured on a microplate reader (ELX 800, Biotek, Winooski, VT, USA) (28).

$P C R$ and reverse transcription-quantitative PCR (RT-qPCR). Total RNA from the NSCLC tissues and cells was isolated using TRIzol reagent (Thermo Fisher Scientific) and the cDNA was generated using the reverse transcription reagent kit (Vazyme Biotech). The PCR assay was performed with a $50 \mu \mathrm{l}$ volume reaction containing $25 \mu \mathrm{l} 2 \mathrm{X}$ Taq master mix, $1 \mu \mathrm{l}$ forward primer $(10 \mu \mathrm{M}), 1 \mu \mathrm{l}$ reverse primer $(10 \mu \mathrm{M})$ and $1 \mu \mathrm{l}$ cDNA on an ABI 2720 thermal cycler with the condition of $94^{\circ} \mathrm{C} / 5 \mathrm{~min}, 35$ cycles of $94^{\circ} \mathrm{C} / 30 \mathrm{sec}, 55^{\circ} \mathrm{C} / 30 \mathrm{sec}$ and $72^{\circ} \mathrm{C} / 30 \mathrm{sec}, 72^{\circ} \mathrm{C} / 7 \mathrm{~min}$. The amplification products were then analyzed by agarose gel electrophoresis. The qPCR experiment was performed with a $20 \mu \mathrm{l}$ volume reaction containing $10 \mu \mathrm{l}$ $2 \mathrm{X}$ qPCR SYBR-Green master mix, $0.4 \mu \mathrm{l}$ forward primer $(10 \mu \mathrm{M}), 0.4 \mu \mathrm{l}$ reverse primer $(10 \mu \mathrm{M}), 1 \mu \mathrm{l} \mathrm{cDNA}$ and $0.4 \mu \mathrm{l}$ 50X ROX reference dye 1 on an ABI 7300 system in triplicate under the following conditions: $95^{\circ} \mathrm{C} / 5 \mathrm{~min}, 40$ cycles of $95^{\circ} \mathrm{C} / 5 \mathrm{sec}$ and $60^{\circ} \mathrm{C} / 30 \mathrm{sec}$. The primers used are shown in Table I. The results were normalized to $\beta$-actin expression and analyzed using the $2^{-\Delta \Delta \mathrm{Cq}}$ method $(29,30)$.

Immunohistochemical (IHC) staining. The slides from the NSCLC tissue array were incubated with the antibodies against IL-17R (dilution 1:100), HMGA1 (dilution 1:250) and cyclin D1 (dilution 1:250), followed by incubation with secondary antibodies (dilution 1:500). The reaction was visualized with a DAB HRP substrate kit. Finally, sections were viewed under a light microscope (Eclipse 90i; Nikon, Tokyo, Japan). The tissues subjected to IHC were scored according to the staining intensity and stained area, and 5 randomly selected fields were analyzed. The scoring of the staining intensity was as follows: negative, 0 ; weak, 1; moderate, 2; and strong, 3 . The scoring of the stained area was as follows: $0 \%, 0 ; 1-25 \%, 1 ; 26-50 \%, 2 ; 51-75 \%, 3$; and 76-100\%, 4 . These scores were multiplied to produce the final score: $0-1$, negative expression; 2-4, weak positive expression; and 6-12, strong positive expression $(31,32)$.

Plasmid construction. The HMGAl expression plasmid was constructed by inserting the complete open reading frame (ORF) of the human HMGAl gene (NM_145899.2) into the pIRES2-EGFP vector (Clontech/Takara Bio, Shiga, Japan). The specific primer sequences are shown in Table I. The pGpU6/GFP/Neo vector carrying small hairpin RNA targeting 
Table I. Specific primers for $\mathrm{qPCR}$ and plasmids construction.

\begin{tabular}{|c|c|c|}
\hline Name & & Primers $\left(5^{\prime} \rightarrow 3^{\prime}\right)$ \\
\hline$H M G A 1$ & $\begin{array}{l}\text { Forward } \\
\text { Reverse }\end{array}$ & $\begin{array}{l}\text { GCTGGTAGGGAGTCAGAAGG } \\
\text { TTGGTTTCCTTCCTGGAGTT }\end{array}$ \\
\hline Cyclin D1 & $\begin{array}{l}\text { Forward } \\
\text { Reverse }\end{array}$ & $\begin{array}{l}\text { GCCACTTGCATGTTCG } \\
\text { GGGCTCCTCAGGTTCA }\end{array}$ \\
\hline$\beta$-actin & $\begin{array}{l}\text { Forward } \\
\text { Reverse }\end{array}$ & $\begin{array}{l}\text { CAGCCATGTACGTTGCTATCCAGG } \\
\text { AGGTCCAGACGCAGGATGGCATG }\end{array}$ \\
\hline pIRES2-HMGAI & $\begin{array}{l}\text { Forward } \\
\text { Reverse }\end{array}$ & $\begin{array}{l}\text { CCGCTCGAGCACTCTTCCACCTGCTCCTT } \\
\text { CCG }^{\mathrm{a} A A T T C A T G G G T C A C T G C T C C T C C T ~} \\
\end{array}$ \\
\hline Cyclin D1-FL & $\begin{array}{l}\text { Forward } \\
\text { Reverse }\end{array}$ & $\begin{array}{l}\text { CGGGGTACCCTGGACGGCTCTTTACGC }^{c} \\
\text { CTAGCTAGCTCTGCTGCTCGCTGCTACT }\end{array}$ \\
\hline Truncate 1 & $\begin{array}{l}\text { Forward } \\
\text { Reverse }\end{array}$ & $\begin{array}{l}\text { CGGGGTACCATGCTCTGAGGCTTGGCTAT }^{\mathrm{c}} \\
\text { CTAGCTAGCTCTGCTGCTCGCTGCTACT }^{\mathrm{d}}\end{array}$ \\
\hline Truncate 2 & $\begin{array}{l}\text { Forward } \\
\text { Reverse }\end{array}$ & $\begin{array}{l}\text { CGGGGTACCAAATTCTAAAGGTGAAGGGACG } \\
\text { CTAGCTAGCTCTGCTGCTCGCTGCTACT }\end{array}$ \\
\hline Truncate 3 & $\begin{array}{l}\text { Forward } \\
\text { Reverse }\end{array}$ & $\begin{array}{l}\text { CGGGGTACCCTCAGGGATGGCTTTTGG }^{c} \\
\text { CTAGCTAGCTCTGCTGCTCGCTGCTACT }\end{array}$ \\
\hline
\end{tabular}

Underlined letters indicate the following restriction sites: ${ }^{\mathrm{a}} \mathrm{X} h \mathrm{I}$; ${ }^{\mathrm{b}} \mathrm{EcoRI}$; ${ }^{\mathrm{c}} \mathrm{KpnI}$; ${ }^{\mathrm{d}} \mathrm{NheI}$.

HMGAl (shHMGAl) was provided by GenePharma (Shanghai, China). The shRNA-targeted sequences of $H M G A l$ gene were as follows: shHMGA1-1, 5'-CAACTCCAGGAAGGAAAC CAA-3'; shHMGA1-2, 5'-CCTTGGCCTCCAAGCAGG AAA-3'; shHMGA1-3, 5'-GAAGGAGGAAGAGGAGGG CAT-3'; and scrambled shRNA control (shCTR), 5'-GTTCTCC GAACGTGTCACGT-3'. In addition, the reporter plasmids carrying cyclin Dl full-length (FL) and truncated promoter plasmids were constructed by inserting the corresponding fragments into the pGL3-basic vector (Promega). The detailed primers are listed in Table I.

Cell culture, stimulation and transfection. The cells were maintained in DMEM with $10 \%$ FBS in an incubator containing $5 \% \mathrm{CO}_{2}$ at $37^{\circ} \mathrm{C}$. For $I L-17$ stimulation, the cells were cultured overnight and starved for $24 \mathrm{~h} ; I L-17$ was then added into the medium at various concentrations $(0,0.5,5,50$ and $500 \mathrm{ng} / \mathrm{ml})$ for different periods of time (according to the needs of distinct experiments). For plasmid transient transfection, $3 \times 10^{5}$ cells were seeded per well in a 6 -well plate. A mixture of $3 \mu \mathrm{g}$ plasmid and $6 \mu \mathrm{l}$ transfection reagent was then added followed by incubation for $48 \mathrm{~h}$. The transfection efficiency was determined by GFP expression at $24 \mathrm{~h}$ following transfection. For $I L-17 R$ siRNA ( $\mathrm{si} I L-17 R$ ) transfection, the cells were seeded in a 6-well plate and cultured overnight, and the mixture of 100 pmol si $I L-17 R$ and $5 \mu 1$ Lipofectamine 2000 was then added followed by $24 \mathrm{~h}$ of incubation. The si $I L-17 R$ was supplied by GenePharma and the sequences were as follows: forward, 5'-CCUGCAGCUGAACACCAAUTT-3' and reverse, 5'-AUUGGUGUUCAGCUGCAGGTT-3'.

Western blot analysis. The cells were lysed using RIPA buffer (Beyotime, Beijing China) and the total protein concentration was measured by BCA assay. The protein samples were loaded (50 $\mu \mathrm{g}$ per well) and electrophoresed on a $10 \%$ SDS-PAGE gel and transferred onto PVDF membranes (Pall Corp., Port Washington, NY, USA). The blots were then blocked with $5 \%$ non-fat milk for $1 \mathrm{~h}$ at room temperature, and probed with the $I L-17 R, H M G A 1$ or cyclin DI antibody overnight at $4^{\circ} \mathrm{C}$, followed by incubation with the rabbit IgG HRP-conjuncated (dilution 1:1,000) antibody for $30 \mathrm{~min}$ at room temperature, and then exposed using regular X-ray film. The dilution of anti- $I L-17 R$, anti-HMGAl and anti-cyclin DI antibodies was 1:500, 1:10,000 and 1:1,000 respectively. The control antibody was $\beta$-actin antibody (Cat. no. AF0003; Beyotime Beijing, China) and the dilution was 1:1,000. Autoradiograms were quantified by densitometry (Quantity One software; Bio-Rad, Hercules, CA, USA).

Prediction of HMGAl response elements. The HMGAl response elements on $c y c l i n D 1$ gene promoter were predicted by using the online software JASPAR (http://jaspar.genereg. net/). Briefly, the matrix model of $H M G A l$ binding element was found and selected, and the promoter sequence of Cyclin Dl gene was then input into the scan window, with the relative profile score threshold set at about $80 \%$. After scanning, the putative sites were displayed.

Luciferase reporter assay. The afore-mentioned promoter reporters were transfected into the A549 cells with a pRL-SV40 vector (Promega), separately. A dual-luciferase reporter reagent was used to measure the promoter activity according to the manufacturer's instructions and as previously described (33).

Chromatin immunoprecipitation (ChIP) assay. ChIP assay was performed using ChIP-grade HMGAl antibody and 
Table II. The characteristics of the patients with non-small cell lung cancer (NSCLC) detected by ELISA.

\begin{tabular}{lr}
\hline Characteristics & No. $(\%)$ \\
\hline Total & 40 \\
Sex & \\
Male & $25(62.5)$ \\
Female & $15(37.5)$ \\
Age & \\
$<60$ & $7(17.5)$ \\
$\geq 60$ & $33(82.5)$ \\
Tumor size & \\
$<5$ cm & $16(40)$ \\
$\geq 5$ cm & $24(60)$ \\
Lymph node metastasis & \\
Negative & $11(27.5)$ \\
Positive & $29(72.5)$ \\
TNM stage & \\
I & $3(7.5)$ \\
II & $11(27.5)$ \\
III & $16(40)$ \\
IV & $10(25)$ \\
Pathological type & \\
Squamous carcinoma & $15(37.5)$ \\
Adenocarcinoma & \\
Large cell carcinoma & \\
Bronchioloalveolar carcinoma & \\
\hline & \\
& \\
& \\
&
\end{tabular}

ChIP-grade protein $\mathrm{G}$ agarose beads in accordance with the manufacturer's instructions provided with the SimpleChIP Plus Enzymatic Chromatin IP kit and as previously described (34). A non-specific rabbit IgG was used as a negative control. PCR and RT-qPCR were performed to analyze the cyclin DI promoter in the ChIP materials. The primers for the cyclin DI promoter fragment in the ChIP assay were as follows: forward, 5'-CCCCATAAATCATCCAGGC-3'; and reverse, 5'-CCCGA GCACCCACAATC-3'.

Cell proliferation assay. Cell proliferation was measured by CCK- 8 and colony formation assays. For CCK-8 assay, based on the manufacturer's instructions, the optical density (OD) values at $450 \mathrm{~nm}$ were documented using a microplate reader (Biotek). For colony formation assay, the cells were seeded in a 6 -well plate at 500 cells/per well. Following culture for 10 days, the cells were fixed and stained with $0.1 \%$ crystal violet. Visible colonies were counted.

Statistical analysis. All data are presented as the means \pm SE. Data analysis was carried out using GraphPad Prism 6.01 (GraphPad Software, San Diego, CA, USA). The significant difference between 2 groups was determined by a Student's t-test. Multi-group comparisons were carried out by one-way ANOVA with Dunnett's post hoc test. Using a Chi-square test, the association of the clinical parameters of the patients with NSCLC with the expression of proteins was analyzed. The correlation between the IHC scores was determined by computing Pearson's correlation coefficient. A P-value $<0.05$ was considered to indicate a statistically significant difference.

\section{Results}

Elevated plasma IL-17 levels, and tissue IL-17R, HMGAI and cyclin D1 expression levels in patients with NSCLC. At the beginning of the present study, we examined the concentration of $I L-17$ in plasma and the expression levels of $I L-17 R, H M G A I$ and cyclin Dl in the tumor tissues from patients with NSCLC. Using ELISA, we found that the plasma IL-17 levels were significantly increased in the 40 cases of NSCLC (the clinical characteristics of the patients are summarized in Table II) compared with the 40 healthy donors (Fig. 1A). Moreover, a marked upregulation in the expression of IL-17R, HMGAI and cyclin Dl in the NSCLC tissues in comparison with the adjacent normal tissues was demonstrated by IHC staining in the NSCLC tissue microarrays ( $n=60$, Fig. 1B and C). Furthermore, we also discovered that the expression of $I L-17 R$, HMGAI and cyclin DI was associated with the tumor size, lymph node metastasis and TNM stage in these patients with NSCLC (Table III). Notably, positive correlations were also found between the expression of the above-mentioned 3 genes in the NSCLC tissues (Fig. 1D). These data thus suggest that the production of $I L-17, I L-17 R, H M G A l$ and cyclin Dl may probably contribute to the development of NSCLC.

IL-17 induces A549 cell proliferation and upregulates HMGAI or cyclin D1 expression. Given that $I L-17, I L-17 R, H M G A 1$ and cyclin $D 1$ expression levels were all elevated in the patients with NSCLC, and the expression of $I L-17 R$ positively correlated with $H M G A 1$ or cyclin Dl expression, we assumed that $I L-17$, as an extracellular stimulus, may trigger NSCLC cell proliferation and upregulate $H M G A l$ and cyclin $D 1$ by binding to $I L-17 R$. Firstly, to determine the most susceptible NSCLC cell line to $I L-17$ stimulation, we assessed $I L-17 R$ expression in different NSCLC cell lines. The results revealed that $I L-17 R$ was markedly overexpressed in the PC9, A549 and SPC-A1 cells in comparison with the human bronchial epithelial $16 \mathrm{HBE}$ cells, particularly in the A549 cells (Fig. 2A). Subsequently, we selected the A549 cells and treated the cells with human recombinant $I L-17$ (i.e., $I L-17 A$ ) and found that A549 cell proliferation (examined by CCK- 8 assay and colony formation assay) was prominently upregulated by $I L-17$ stimulation in a dose-dependent manner, particularly when the $I L-17$ concentration reached 50 and $500 \mathrm{ng} / \mathrm{ml}$ (Fig. 2B-D). In addition, to ascertain whether $I L-17$ increases $H M G A l$ and cyclin D1 expression as well as the optimal time-point for the $I L-17$-induced production of $H M G A I$ and cyclin $D 1$, we stimulated the A549 cells with $I L-17(50 \mathrm{ng} / \mathrm{ml})$ for different periods of time and detected the transcription and expression of the afore-mentioned two genes by RT-qPCR and western blot analysis. The results revealed that the mRNA and protein expression levels of $H M G A 1$ and cyclin $D 1$ were significantly increased at $2 \mathrm{~h}(H M G A 1)$ or $3 \mathrm{~h}$ (cyclin Dl) and both peaked at $6 \mathrm{~h}$ (Fig. 2E-G). These results indicate that $I L-17$ not only induces A549 cell proliferation, but also increases the expression of HMGAl and cyclin Dl. 
A

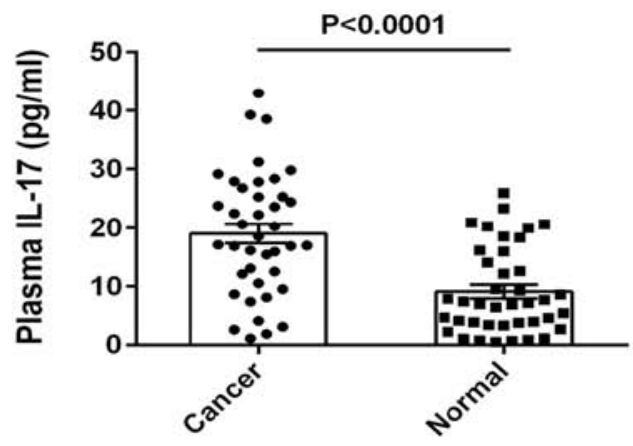

B

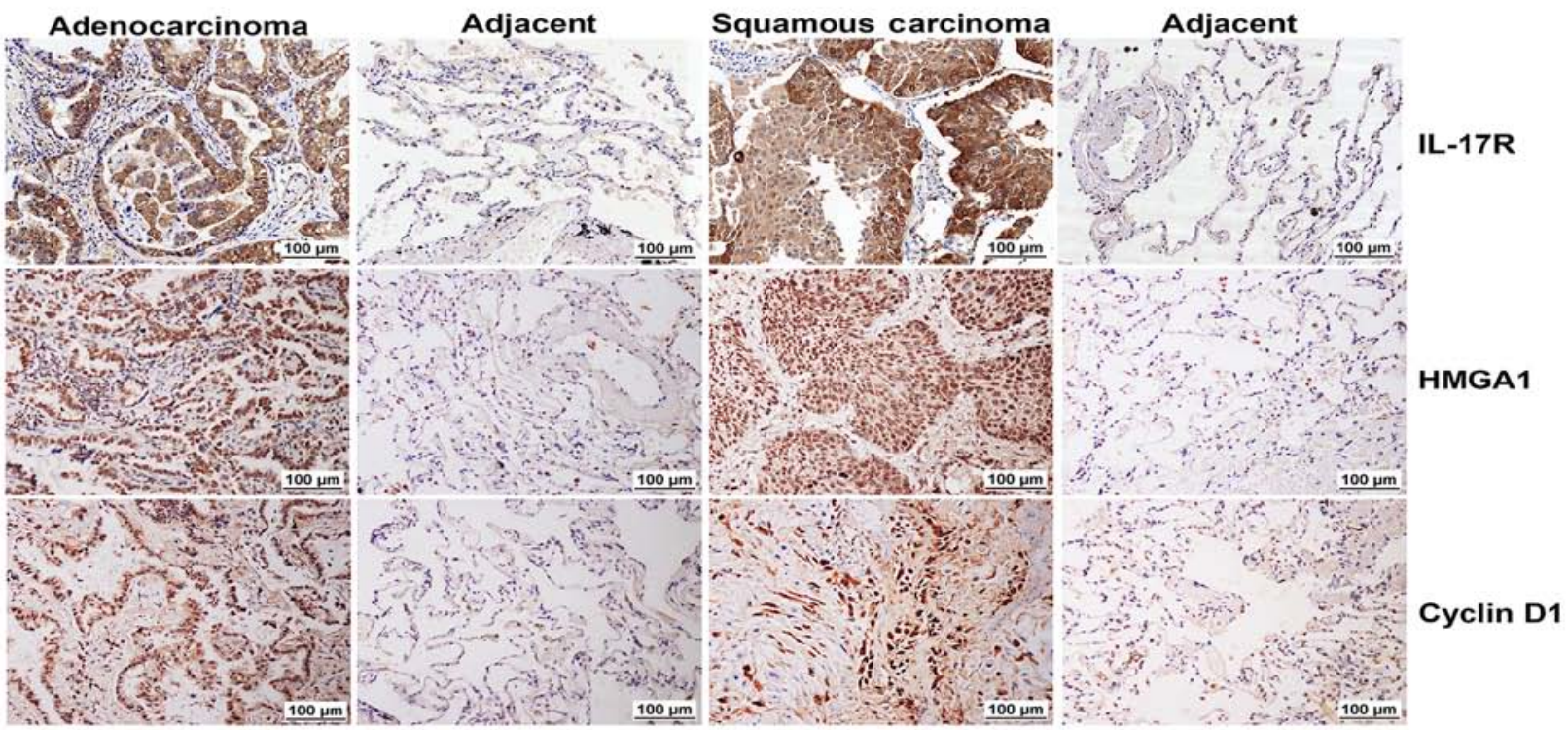

C
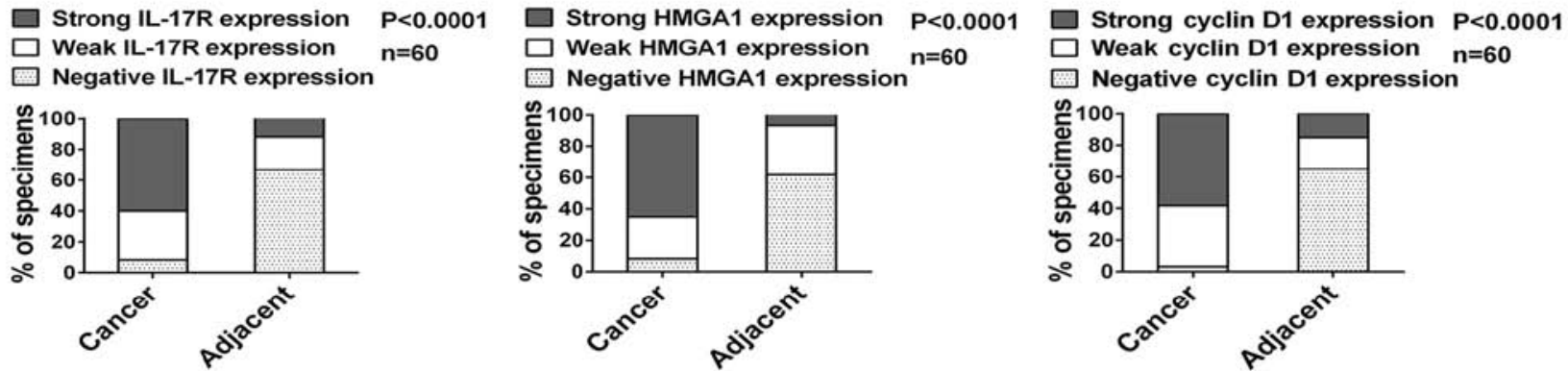

D
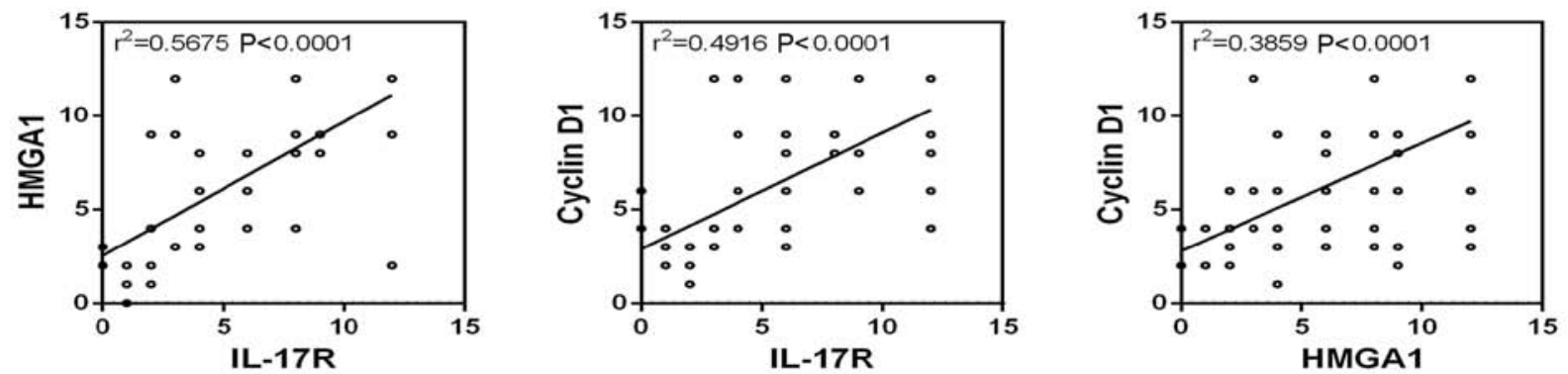

Figure 1. Plasma IL-17 concentration and tissue IL-17R, HMGA1 and cyclin D1 expression levels in patients with non-small cell lung cancer (NSCLC). (A) Quantification of IL-17 in plasma samples from patients with NSCLC and healthy donors. Data are presented as the means \pm SE. (B) Representative images of IL-17R, HMGA1 and cyclin D1 expression in NSCLC tissues and corresponding adjacent normal tissues by IHC staining (n=60). (C) Statistical analysis of IHC staining intensity and the staining area of the above-mentioned proteins. The percentages of negative, week or strong expression of IL-17R, HMGA1 and cyclin D1 in NSCLC tissues are shown. (D) Correlations of IHC staining scores between IL-17R, HMGA1 and cyclin D1. Pearson's correlation coefficient was computed. HMGA1, high-mobility group A1. 
A

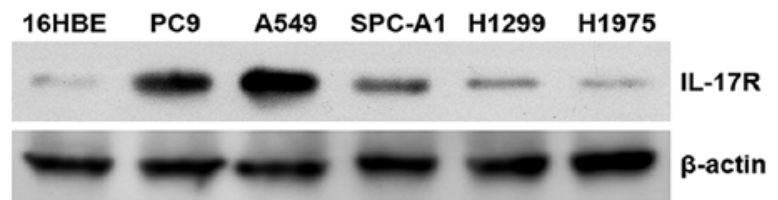

B

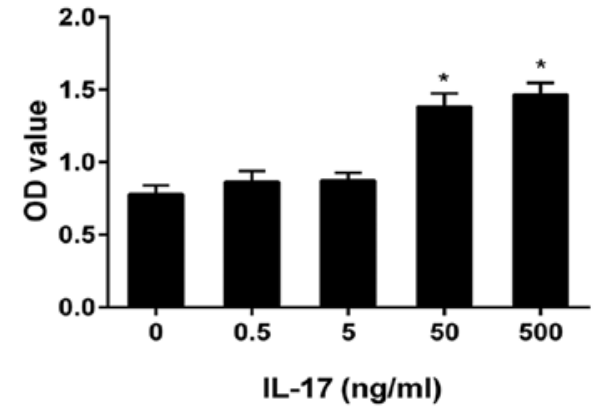

C

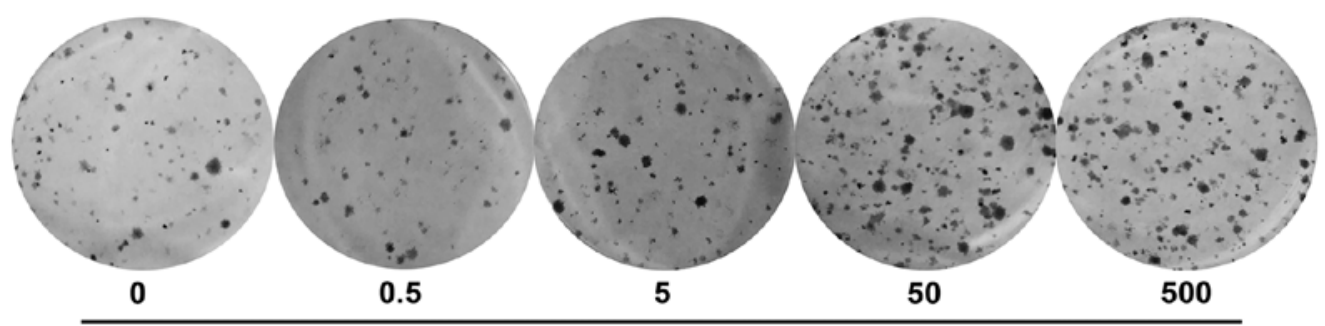

IL-17 (ng/ml)

D

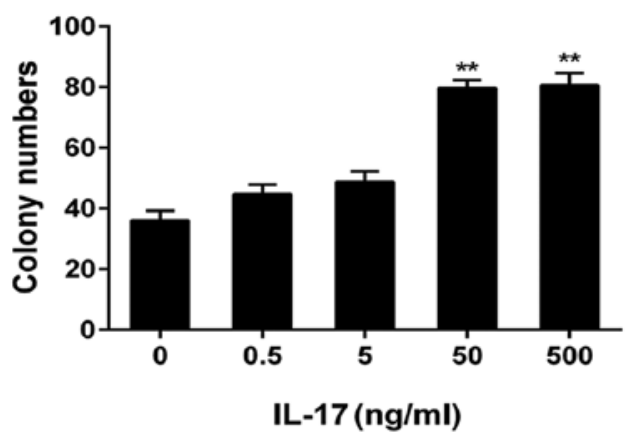

$\mathbf{F}$

IL-17 $50 \mathrm{ng} / \mathrm{ml}(\mathrm{h})$

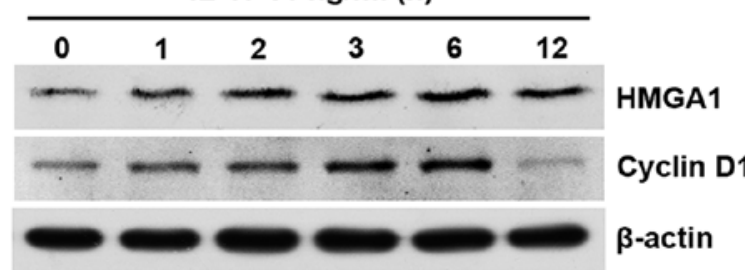

E

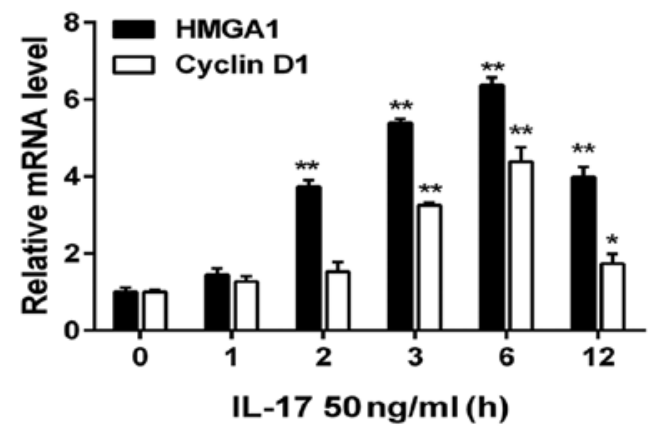

G

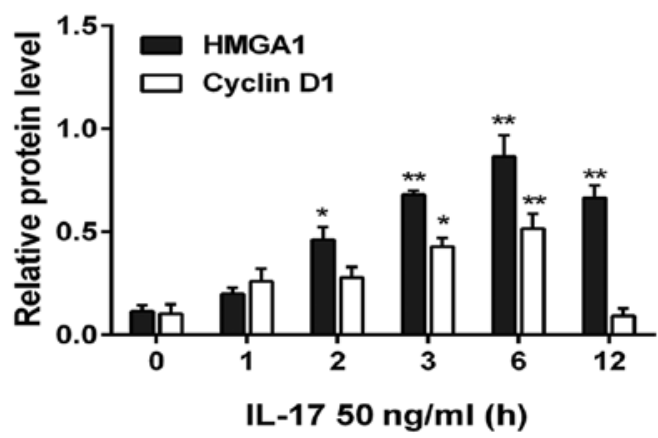

Figure 2. Cell proliferation, and mRNA and protein levels of HMGA1 and cyclin D1 in A549 cells upon IL-17 stimulatoin. (A) The IL-17R protein expression in various NSCLC cell lines examined by western blot analysis. (B) A549 cells were stimulated with various concentrations of recombinant IL-17 (IL-17A) for $72 \mathrm{~h}$ following serum starvation. CCK-8 assay was performed to detect cell viability (OD value). (C and D) Colony formation of the A549 cells under IL-17 stimulation at various concentrations. (C) A representative image and (D) quantification of the colonies are shown. (E-G) A549 cells were exposed to $50 \mathrm{ng} /$ $\mathrm{ml} \mathrm{IL-17} \mathrm{for} \mathrm{different} \mathrm{periods} \mathrm{of} \mathrm{time,} \mathrm{and} \mathrm{the} \mathrm{(E)} \mathrm{mRNA} \mathrm{or} \mathrm{(F} \mathrm{and} \mathrm{G)} \mathrm{protein} \mathrm{levels} \mathrm{of} \mathrm{HMGA1} \mathrm{and} \mathrm{cyclin} \mathrm{D1} \mathrm{were} \mathrm{examined} \mathrm{by} \mathrm{RT-qPCR} \mathrm{and} \mathrm{western} \mathrm{blot}$ analysis, respectively. All data are presented as the means $\pm \mathrm{SE}$ from 3 independent experiments, ${ }^{*} \mathrm{P}<0.05$ and ${ }^{* *} \mathrm{P}<0.01 \mathrm{vs} .0 \mathrm{ng} / \mathrm{ml} \mathrm{IL-17} \mathrm{or} 50 \mathrm{ng} / \mathrm{ml} \mathrm{IL}-17 \mathrm{at}$ 0 h. HMGA1, high-mobility group A1.

IL-17R knockdown or IL-17 neutralization suppresses IL-17induced A549 cell proliferation, HMGAl and cyclin DI upregulation. To further confirm that $I L-17$ stimulation promotes A549 cell proliferation and increases the expression of $H M G A l$ or cyclin $D I$ by binding to $I L-17 R$, we subjected the A549 cells to si $I L-17 R$ transfection or $I L-17$ antibody incubation, prior to treatment with $I L-17$ and then examined cell proliferation and the levels of the two above-mentioned proteins. The results of CCK- 8 assay and colony formation assay revealed that the viability (OD value) and the colony 
Table III. Association between $I L-17 R / H M G A 1 /$ cyclin D1 expression with the clinicopathological characteristics of the patients with non-small cell lung cancer (NSCLC).

\begin{tabular}{|c|c|c|c|c|c|c|c|c|c|c|}
\hline \multirow[b]{2}{*}{ Characteristic } & \multirow[b]{2}{*}{ Total } & \multicolumn{2}{|c|}{$I L-17 R$ expression } & \multirow[b]{2}{*}{ P-value ${ }^{a}$} & \multicolumn{2}{|c|}{$H M G A 1$ expression } & \multirow[b]{2}{*}{ P-value ${ }^{a}$} & \multicolumn{2}{|c|}{ Cyclin D1 expression } & \multirow[b]{2}{*}{ P-value ${ }^{a}$} \\
\hline & & $\begin{array}{l}\text { Weak and } \\
\text { negative }\end{array}$ & Strong & & $\begin{array}{l}\text { Weak and } \\
\text { negative }\end{array}$ & Strong & & $\begin{array}{l}\text { Weak and } \\
\text { negative }\end{array}$ & Strong & \\
\hline & 60 & 24 & 36 & & 21 & 39 & & 25 & 35 & \\
\hline \multicolumn{11}{|l|}{ Sex } \\
\hline Male & 45 & 15 & 30 & 0.0679 & 17 & 28 & 0.4346 & 17 & 28 & 0.2899 \\
\hline Female & 15 & 9 & 6 & & 4 & 11 & & 8 & 7 & \\
\hline \multicolumn{11}{|l|}{ Age (years) } \\
\hline$<60$ & 26 & 11 & 15 & 0.7497 & 10 & 16 & 0.623 & 11 & 15 & 0.9298 \\
\hline$\geq 60$ & 34 & 13 & 21 & & 11 & 23 & & 14 & 20 & \\
\hline \multicolumn{11}{|l|}{ Tumor size } \\
\hline$<5 \mathrm{~cm}$ & 35 & 22 & 13 & $<0.0001^{\mathrm{b}}$ & 19 & 16 & $0.0002^{\mathrm{b}}$ & 4 & 31 & $<0.0001^{\mathrm{b}}$ \\
\hline$\geq 5 \mathrm{~cm}$ & 25 & 2 & 23 & & 2 & 23 & & 21 & 4 & \\
\hline \multicolumn{11}{|l|}{ Lymph node metastasis } \\
\hline Negative & 30 & 18 & 12 & $0.0016^{\mathrm{b}}$ & 16 & 14 & $0.0029^{\mathrm{b}}$ & 19 & 11 & $0.0007^{\mathrm{b}}$ \\
\hline Positive & 30 & 6 & 24 & & 5 & 25 & & 6 & 24 & \\
\hline \multicolumn{11}{|l|}{ TNM stage } \\
\hline I & 19 & 16 & 3 & $<0.0001^{\mathrm{b}}$ & 11 & 8 & $0.0374^{\mathrm{b}}$ & 3 & 16 & $0.0002^{\mathrm{b}}$ \\
\hline II & 27 & 7 & 20 & & 6 & 21 & & 10 & 17 & \\
\hline III & 14 & 1 & 13 & & 4 & 10 & & 12 & 2 & \\
\hline \multicolumn{11}{|l|}{ Pathological type } \\
\hline Squamous carcinoma & 20 & 6 & 14 & 0.3728 & 6 & 14 & 0.0861 & 7 & 13 & 0.2566 \\
\hline Adenocarcinoma & 20 & 9 & 11 & & 5 & 15 & & 11 & 9 & \\
\hline Large cell carcinoma & 10 & 3 & 7 & & 7 & 3 & & 5 & 5 & \\
\hline $\begin{array}{l}\text { Bronchioloalveolar } \\
\text { carcinoma }\end{array}$ & 10 & 6 & 4 & & 3 & 7 & & 2 & 8 & \\
\hline
\end{tabular}

${ }^{\mathrm{a} C h i}$-square test; ${ }^{\mathrm{b}} \mathrm{P}<0.05 ; H M G A 1$, high-mobility group A1.

numbers of A549 cells were greatly multiplied following treatment with $I L-17$; however, these effects were notably reversed by the silencing of $I L-17 R$ with si $I L-17 R$ or by the neutralization of $I L-17$ with anti- $I L-17$ antibody (Fig. 3A-C). Similarly, transfection with si $I L-17$ or incubation with anti- $I L-17$ also significantly decreased the $I L$ - 17 -induced mRNA and protein expression of HMGAl and cyclin D1 in the A549 cells (Fig. 3D-F). These results further denote that $I L-17$ effectively promotes the proliferation, and increases the expression of HMGAl and cyclin Dl in A549 cells through its interaction with IL-17R.

HMGA1 contributes to IL-17-induced A549 cell proliferation and cyclin D1 production. It has been reported that HMGA1 is a transcription factor which can activate the transcription of downstream target genes and finally increase their expression $(35,36)$. Since our experiments verified that $H M G A 1$ and cyclin Dl expression levels were increased in the process of $I L$-17-induced A549 cell proliferation, and the expression phase of $H M G A l$ was earlier than that of $c y c l i n D 1$, we hypothesized that $H M G A l$ itself may enhance cyclin Dl transcription and expression, leading to an increment in cell proliferation, and that the absence of $H M G A 1$ may impede the afore-mentioned phenomena mediated by $I L-17$. To confirm our hypothesis, we first constructed the $H M G A l$ overexpression plasmid (pIRES2-HMGAl) and the plasmid carrying small hairpin RNA targeting HMGAl (shHMGAl) and examined the transfection efficiency of these plasmids (Fig. 4A-C). Subsequently, CCK-8 and colony formation assays were performed. As was expected, A549 cell proliferation was markedly elevated following $H M G A 1$ overexpression, whereas the knockdown of HMGA1 markedly suppressed cell proliferation upon IL-17 stimulation (Fig. 4D-F). In addition, the mRNA and protein levels of cyclin DI were eminently upregulated or downregulated when $H M G A 1$ was overexpressed or silenced with $I L-17$ treatment, respectively (Fig. 4G-I), indicating that IL-17-induced HMGAl expression exerts a promoting effect on the proliferation of and cyclin D1 expression in A549 cells mediated by IL-17.

IL-17 activates the cyclin D1 gene promoter through HMGAI binding to its response element on the promoter. As mentioned 
A

B

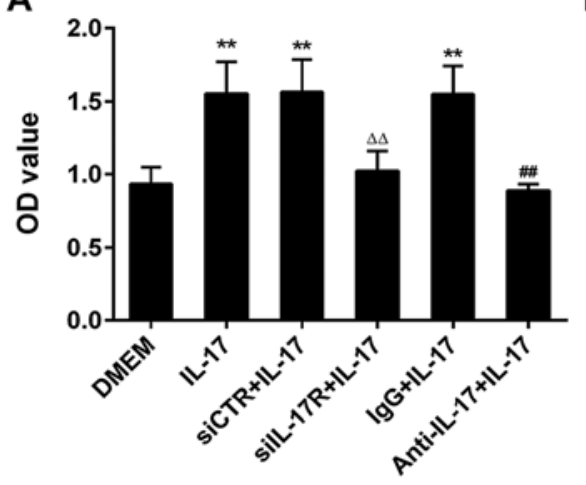

C

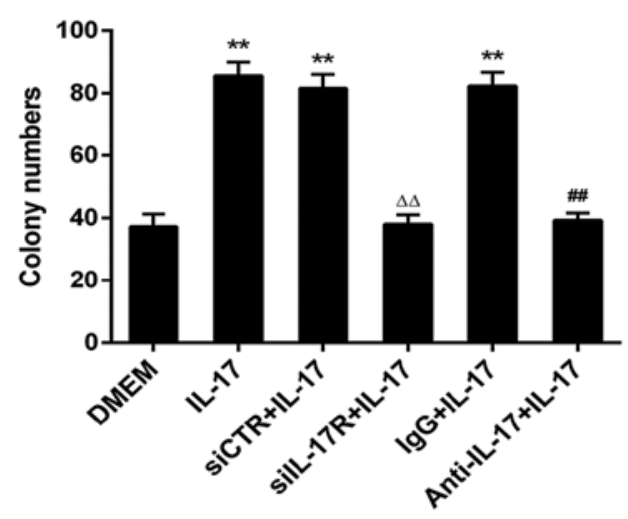

$\mathbf{E}$

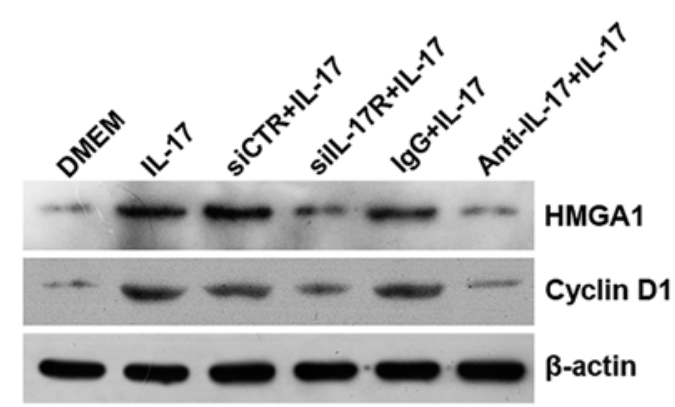

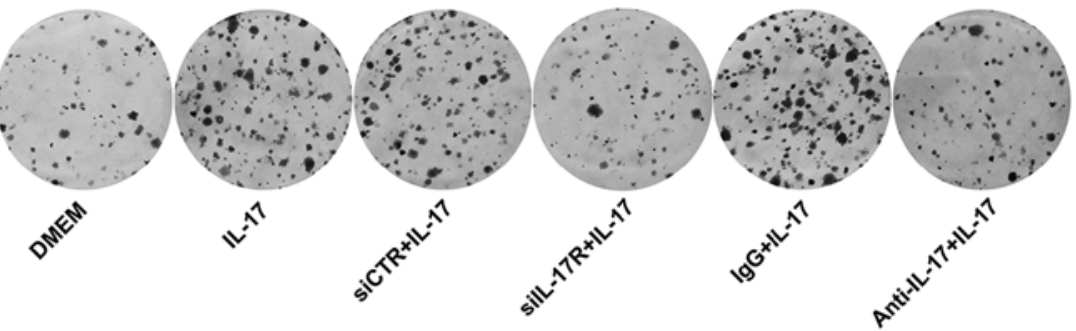

D

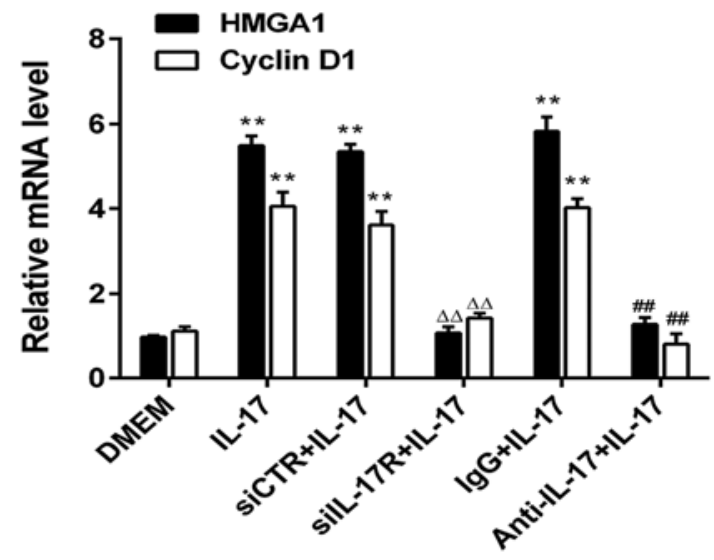

$\mathbf{F}$

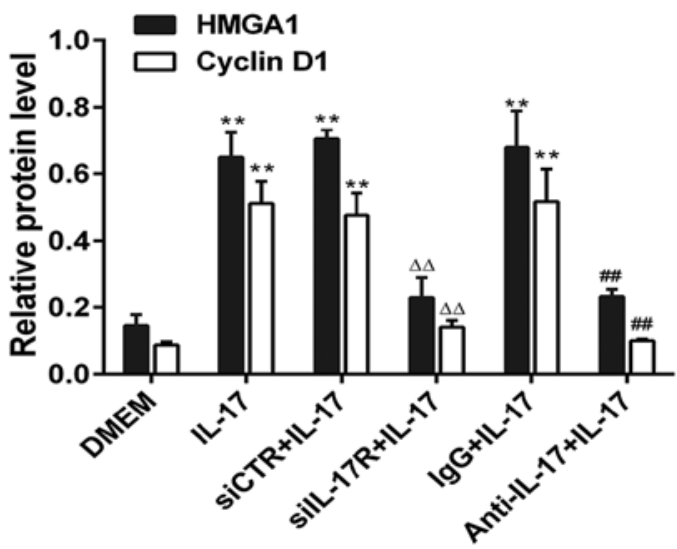

Figure 3. Alterations in cell proliferation and the expression of HMGA1 or cyclin D1 in IL-17-stimulated A549 cells following the silencing of IL-17R or the neutralization of IL-17. The A549 cells were transfected with silL-17R (scrambled siCTR as a control) for $24 \mathrm{~h}$ or pre-treated with a neutralizing antibody against IL-17 (IgG from same species as a control) for $30 \mathrm{~min}$, followed by IL-17 stimulation at $50 \mathrm{ng} / \mathrm{ml}$. (A) Following $72 \mathrm{~h}$ of stimulation, CCK-8 assay were performed to detect cell viability (OD value). (B and C) Cells were seeded and allowed to form colonies for another 10 days. (B) Representative images of colony formation and (C) the numbers of visible colonies are shown. (D-F) Following exposure to IL-17 for $6 \mathrm{~h}$, the (D) mRNA or (E and F) protein levels of HMGA1 and cyclin D1 in the A549 cells were measured by RT-qPCR or western blot analysis. Data are expressed as the means \pm SE from 3 independent experiments, ${ }^{* *} \mathrm{P}<0.01$ vs. DMEM group, ${ }^{\Delta \Delta} \mathrm{P}<0.01$ vs. siCTR + IL-17 group, and ${ }^{\# \#} \mathrm{P}<0.01$ vs. IgG + IL-17 group. HMGA1, high-mobility group A1.

earlier, $I L-17$ stimulation increased $c y c l i n D 1$ expression via the transcription factor, $H M G A 1$; hence, we wished to determine whether $I L-17$ activates the cyclin $D 1$ gene promoter through HMGA1. For this purpose, we carried out luciferase reporter assay, and found that $I L-17$ markedly increased cyclin DI promoter activity at $3 \mathrm{~h}$ (peaked at $6 \mathrm{~h}$ ) after the A549 cells were stimulated (Fig. 5A). In addition, the overexpression of HMGAl markedly activated the full length of the cyclin DI promoter (cyclin D1-FL, $-2,099$ to $+86 \mathrm{nt}$ ), whereas the activity of cyclin D1-FL markedly decreased in accordance with
HMGAl knockdown (Fig. 5B). Subsequently, to locate the region in which $H M G A 1$ binds to on the cyclin Dl promoter, we first predicted three potential $H M G A 1$ response elements ( $-1,700$ to $-1,691 \mathrm{nt},-1,026$ to $-1,017 \mathrm{nt}$, and -139 to $-130 \mathrm{nt})$ using the online software JASPAR (http://jaspar.genereg.net/), and then constructed three truncated promoter reporters based on the prediction (Fig. 5C), which were truncate 1 (T1, -1,672 to $+86 \mathrm{nt}$ ), truncate 2 (T2, $-1,026$ to $+86 \mathrm{nt}$ ) and truncate 3 (T3, -139 to $+86 \mathrm{nt})$. By luciferase assay, we confirmed that in the A549 cells treated with $I L-17$ or transfected with the 
A
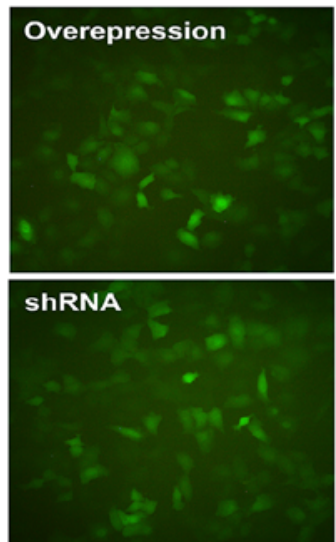

GFP
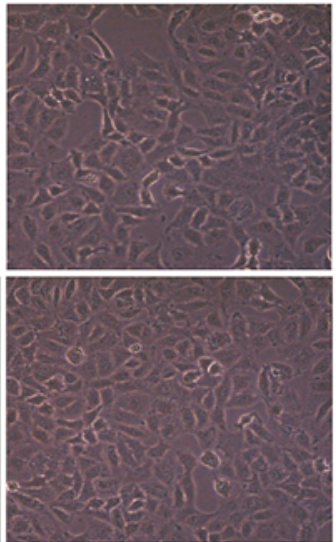

White light
B

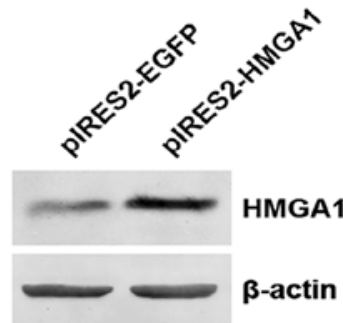

C

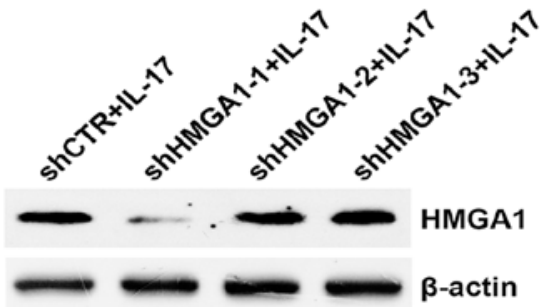

D

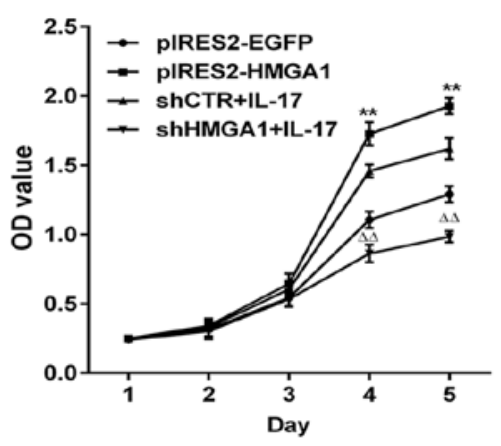

F

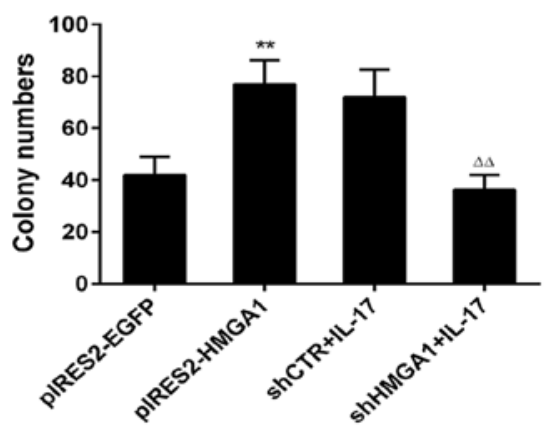

H

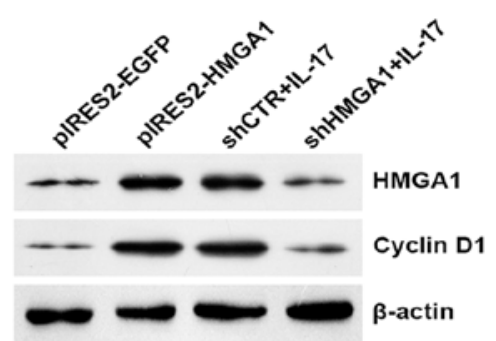

E

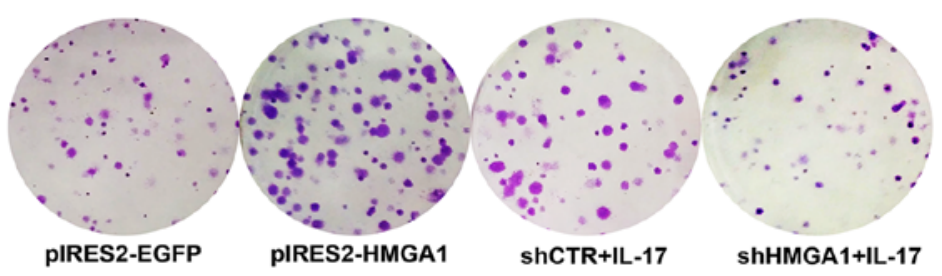

G

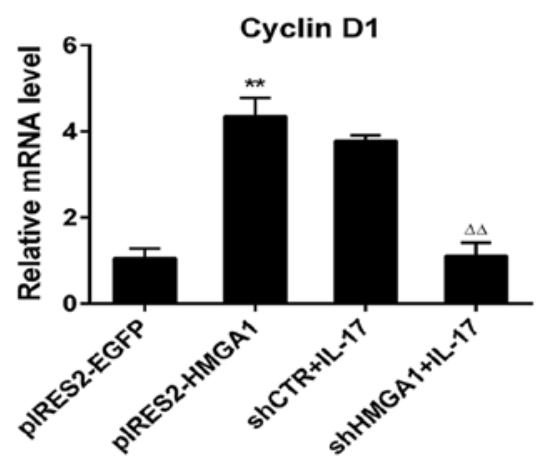

I

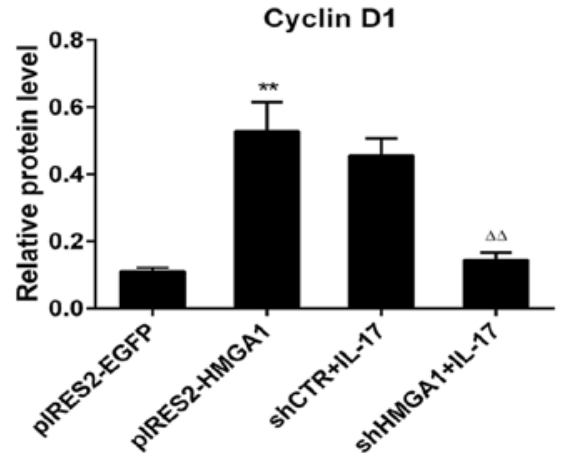

Figure 4. Role of HMGA1 in IL-17-induced cell proliferation and the expression of cyclin D1 in A549 cells. A549 cells were transfected with an HMGA1 overexpression vector (pIRES2-HMGA1, pIRES2-EGFP as control) or shRNA expression plasmid (shHMGA1, scrambled shCTR as control) for 48 h. In addition, cells transfected wiht shRNA vectors were treated with $50 \mathrm{ng} / \mathrm{ml}$ IL-17 for $6 \mathrm{~h}$. (A) The transfection efficiency was determined by GFP expression at $24 \mathrm{~h}$ in A549 cells (x200 magnification). (B) The resutls of western blot analysis revealed that pIRES2-HMGA1 successfully enhanced HMGA1 expression in the A549 cells. (C) Western blot analysis was used to identify the optimal shRNA for HMGA1 silencing, and it was found that shHMGA1-1 markedly downregulated HMGA1 expression in the A549 cells upon IL-17 stimulation. (D) Cells were seeded in a 96-well plate and CCK-8 assay were used to monitor cell proliferation at the indicated time-points. (E and F) Colony formation assay was performed by culturing the cells for a further 10 days, and (E) a representative image or (F) the number of colonies are shown. (G-I) Cyclin D1 (G) mRNA or (H and I) protein expression in the A549 cells transfected with the afore-mentioned plasmids was assessed by RT-qPCR or western blot analysis. Data are presented as the means \pm SE from at least 3 independent repeated experiments. ${ }^{* *} \mathrm{P}<0.01$ vs. pIRES2-EGFP, ${ }^{\Delta \Delta} \mathrm{P}<0.01$ vs. shCTR + IL-17 group. HMGA1, high-mobility group A1. 
A

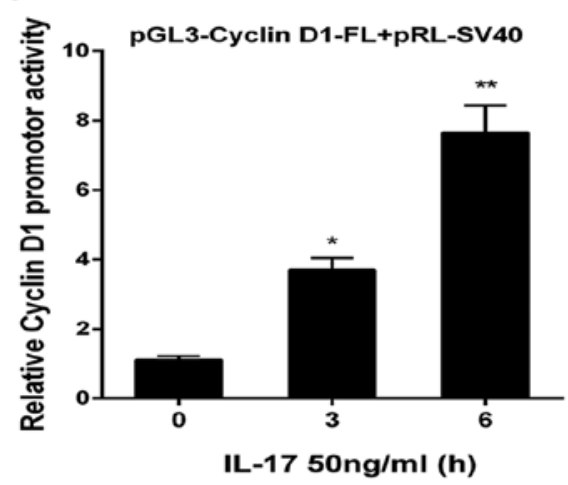

B

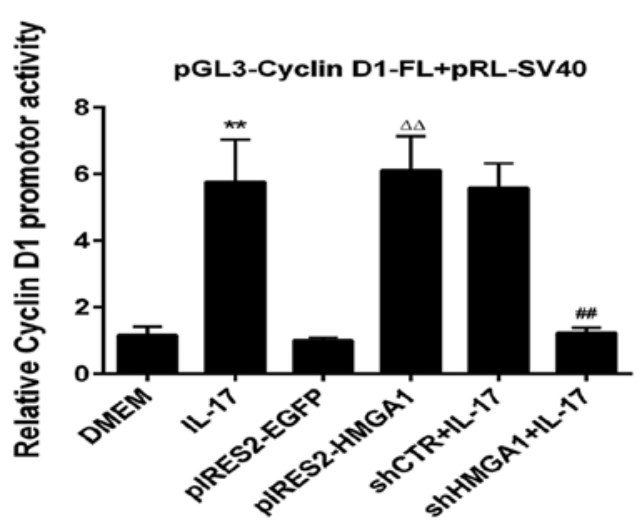

C
Cyclin D1 promoter
Potential HMGA1 response element

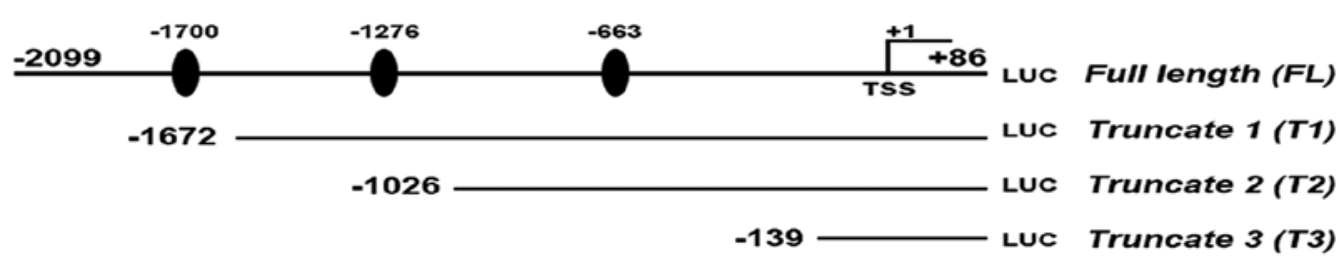

D

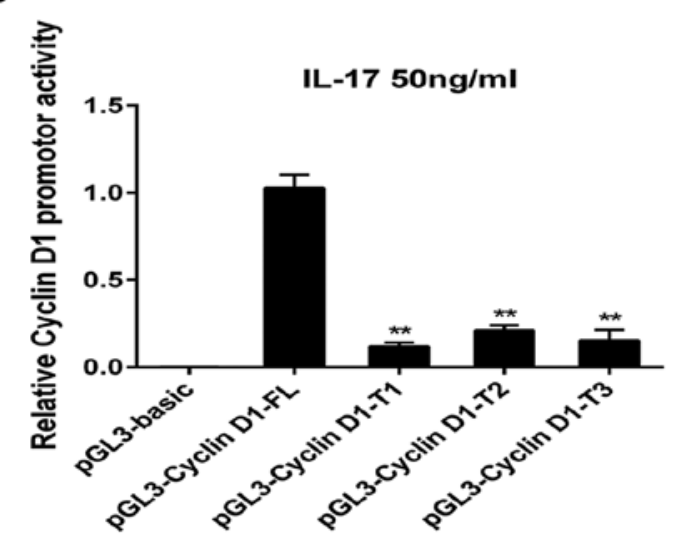

$\mathbf{F}$

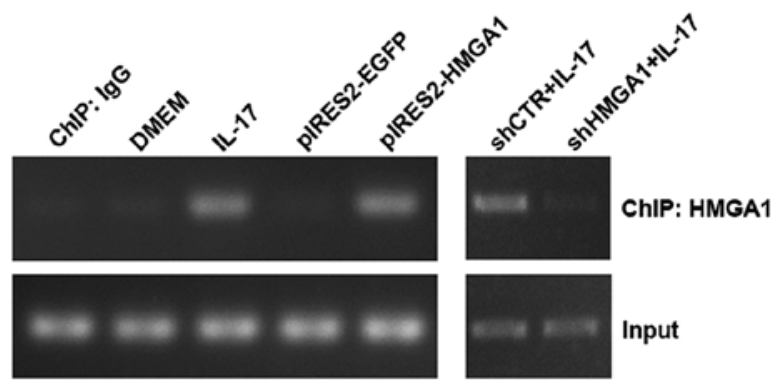

Cyclin D1 promoter (-1752 to $-1622 \mathrm{nt})$

E

G
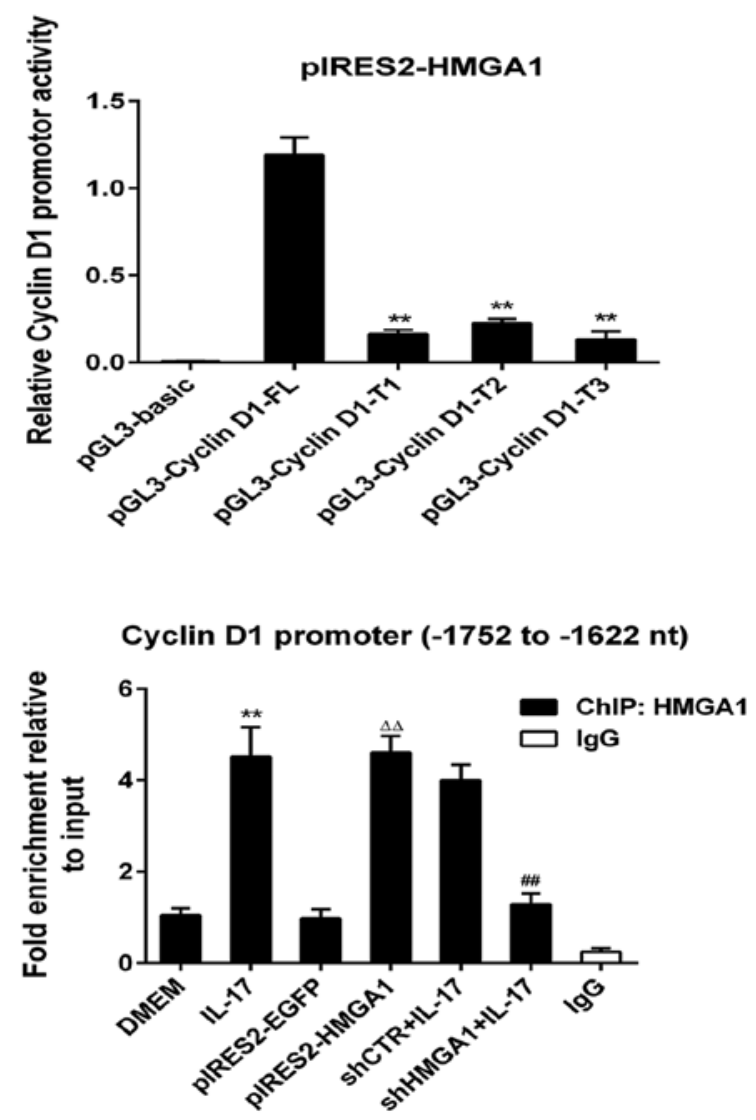

Figure 5. Identification of cyclin D1 promoter activity in A549 cells upon IL-17 stimulation and the HMGA1 binding element on the cyclin D1 promoter. (A) A549 cells were transfected with the full-length promoter of cyclin D1 (cyclin D1-FL, $-2,099$ to $+86 \mathrm{nt}$ ), followed by stimulation with IL-17 at $50 \mathrm{ng} / \mathrm{ml}$ for 3 or 6 h. Luciferase reporter assay was performed to examine the activity of the cyclin D1 promoter in A549 cells at different time-points. ${ }^{*} \mathrm{P}<0.05$ and ${ }^{* * *} \mathrm{P}<0.01$ vs. 0 h. (B) Cyclin D1-FL was co-transfected with pIRES2-HMGA1 or with shHMGA1 into A549 cells, followed by IL-17 stimulation. The activity of the cyclin D1-FL promoter was assessed by reporter assay. ${ }^{* *} \mathrm{P}<0.01$ vs. DMEM, ${ }^{\Delta \Delta} \mathrm{P}<0.01$ vs. pIRES2-EGFP, ${ }^{\# \#} \mathrm{P}<0.01$ vs. shCTR + IL-17 group. (C) Schematic representation of the cyclin D1 promoter and the predicted HMGA1 response elements on it. The reporter plasmids carrying truncated promoter regions were constructed as indicated. (D and E) Using luciferase assay, the activity of cyclin D1-FL and three truncated promoters (cyclin D1-T1, cyclin D1-T2 and cyclin D1-T3) was measured either in the presence of (D) IL-17 stimulation or (E) HMGA1 overexpression. ${ }^{* *} \mathrm{P}<0.01$ vs. pGL3-cyclin D1-FL. (F and G) A549 cells were transfected with pIRES2-HMGA1 or with shHMGA1 followed by exposure to IL-17. Anti-HMGA1 was used to perform ChIP assay. (F) PCR and (G) RT-qPCR were then applied to quantify the binding of HMGA1 to the indicated region of the cyclin D1 promoter. ${ }^{* *} \mathrm{P}<0.01 \mathrm{vs}$. DMEM, ${ }^{\Delta \Delta} \mathrm{P}<0.01 \mathrm{vs}$. pIRES2-EGFP, ${ }^{\# \#} \mathrm{P}<0.01$ vs. shCTR + IL-17 group. All data are shown as the means \pm SE from 3 independent experiments. HMGA1, high-mobility group A1. 


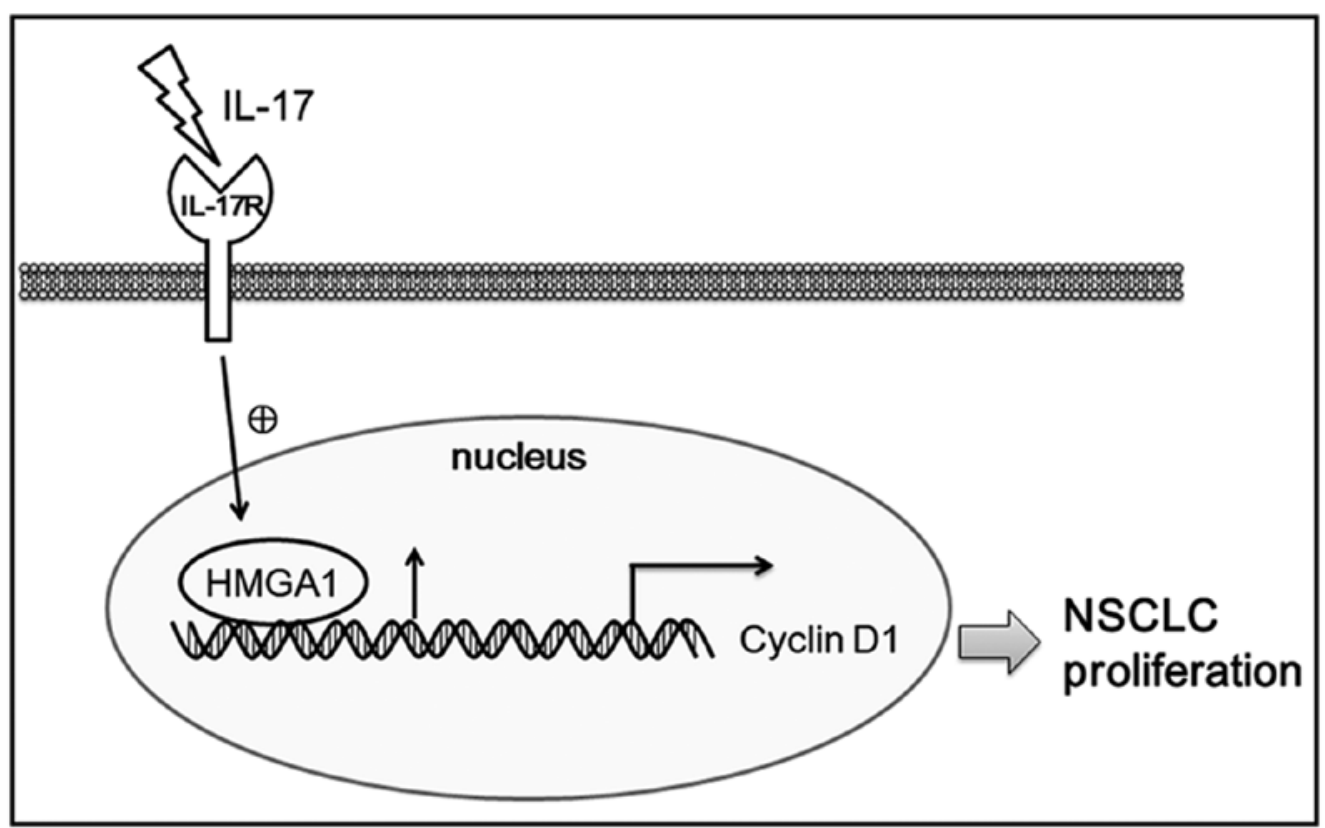

Figure 6. Putative schematic diagram of the molecular mechanisms underlying non-small cell lung cancer (NSCLC) proliferation induced by IL-17 through HMGA1 and cyclin D1. HMGA1, high-mobility group A1.

HMGAl overexpression plasmid, the activity of all cyclin DI truncated promoters was markedly decreased compared to that of the cyclin D1-FL. However, no statistically significant differences were observed between the luciferase activity in these three truncated reporters (Fig. 5D and E), suggesting that the most effective $H M G A l$ binding element may be located in the region of $-2,099$ to $-1,673 \mathrm{nt}$ on the cyclin D1 promoter (probably $-1,700$ to $-1,691 \mathrm{nt}$ ). Finally, to determine the exact binding of $H M G A l$ to the above-mentioned element, a ChIP assay was performed using antibody against $H M G A 1$, and the region $-1,752$ to $-1,622 \mathrm{nt}$ (containing $-1,700$ to $-1,691 \mathrm{nt}$ ) was then amplified by RT-qPCR. The results revealed that the binding of HMGAl to the indicated fragment of the cyclin D1 promoter was prominently increased both in the A549 cells subjected to $I L-17$ stimulation or in those transfected with the HMGAl overexpression vector; however, this binding was diminished when $H M G A l$ was silenced (Fig. $5 \mathrm{~F}$ and $\mathrm{G}$ ). These findings imply that $I L-17$ enhances cyclin $D I$ promoter activity via $H M G A 1$, directly binding to its response element in the region $-1,752$ to $-1,622 \mathrm{nt}$, which eventually results in an increased cyclin D1 expression and A549 cell proliferation.

\section{Disscussion}

NSCLC is one of the most common types of malignancy worldwide $(1,2)$. Accumulating evidence suggests that NSCLC is a typical inflammation-associated cancer $(3,4,37,38)$, and $I L-17$ as a pro-inflammatory cytokine, has been reported to be closely associated with NSCLC cell proliferation and development $(7,39)$; however, the mechanisms underlying $I L-17$-induced NSCLC cell proliferation have not yet been fully elucidated.

It has been well documented that cell proliferation is associated with extracellular stimuli and proliferative molecule expression $(7,40,41)$. $I L-17 A$ (namely $I L-17)$, as a stimulus, is mainly secreted by activated T cells, mononuclear cells, dendritic cells (DCs) and other cells, including tumor cells $(5,6)$. Recent studies have revealed that $I L-17$ overproduction contributes to the inflammatory microenvironment for NSCLC cell proliferation and growth $(5,11)$. Moreover, $H M G A 1$ as a transcription factor and cyclin DI as a proliferative protein can also promote cancer cell proliferation (40-43). Hence, in this study, in order to better understand the pathogenesis of $I L-17$-induced NSCLC cell proliferation, we first detected the level of $I L-17$ in plasma, and the expression of $I L-17 R, H M G A l$ as well as that of cyclin Dl in the tumor tissues of patients with NSCLC. Our results revealed the markedly elevated production of $\mathrm{I} L-17, I L-17 R, H M G A I$ and cyclin Dl, and positive correlations between $I L-17 R, H M G A 1$ and cyclin DI expression. Besides, we also confirmed the positive correlation between $I L-17 R, H M G A 1$ and cyclin DI expression with tumor size, lymph node metastasis and the TNM stage of patients with NSCLC. These results indicate that the overexpression of these molecules mentioned above, not only exists in patients with NSCLC, but may also be related to NSCLC growth.

As is known, $I L-17$ plays a crucial role in controlling inflammation (8) and promoting tumor cell proliferation such as colitis-associated cancer (44) and NSCLC (39). Moreover, $I L-17$, as an extracellular stimulus, can activate several cell signaling pathways, such as p38/c-Fos and JNK/c-Jun (45), and $H M G A l$ has been reported to be a direct transcriptional target of $c$-Jun (46), indicating that $I L-17$ may promote the transcription of the HMGAl gene. However, whether HMGAl and cyclin DI expression is upregulated in NSCLC cells upon $I L-17$ stimulation remains elusive. Our in vitro experiments demonstrated an enhanced proliferation of, as well as an increased HMGAl and cyclin D1 expression in A549 cells exposed to $I L-17$. Additionally, $I L-17 R$ knockdown with si $I L-17 R$ or the neutralizing of $I L-17$ with anti- $I L-17$ antibody 
significantly decreased the proliferation and $H M G A 1$ or cyclin D1 expression in the A549 cells. These data thus suggest that $I L-17$ markedly induces A549 cell proliferation through $H M G A 1$ and cyclin DI production.

Reportedly, HMGAl protein acts within the nucleus of mammalian cells as an architectural transcription factor $(40,42)$; however, the cytoplasmic/mitochondrial localization of $H M G A 1$ protein in multiple cell types has also been found (35), suggesting that HMGAl may undergo nucleocytoplasmic translocation during some biological processes. Moreover, HMGAl can modulate gene expression by altering the chromatin structure and orchestrating the assembly of transcription factor complexes to augment target gene promoter activity (42). Furthermore, HMGA1 markedly facilitates the proliferation of several types of cancer cells, such as pancreatic cancer (36), breast cancer (47), ovarian cancer (48), colon cancer (49) and thyroid cancer (21). Additionally, cyclin $D 1$ also regulates cyclin-dependent kinase $(C D K) 4$ and $C D K 6$ to promote cell cycle transition from the G1 to the S phase (50-52). However, even though it has already been mentioned in the literature that during the process of pancreatic cancer cell proliferation, HMGA1 regulates the transcription of the cyclin $D 1$ gene, which promotes cell cycle G1/S transition through $C D K 4$ and CDK6 (36), the effects of HMGAl on cyclin Dl gene transcription, expression and cell proliferation in NSCLC and the specific mechanisms involved have not yet been fully determined. In this study, the $I L-17$-induced expression phase of $H M G A I$ was slightly earlier than that of cyclin $D 1$; we thus speculated that the upregulation of HMGAI induced by $I L-17$ may have effect on cyclin D1 expression and the proliferation of A549 cells. By the overexpression or knockdown of HMGAl in the presence of $I L-17$ stimulation, we found that the proliferation of and cyclin D1 expression in A549 cells were positively associated with $H M G A 1$ expression, and so was the cyclin Dl promoter activity, suggesting that $H M G A l$ expression can trigger cyclin $D 1$ gene transcription. Further experiments affirmed that $H M G A l$ can directly bind to the promoter of the cyclin DI gene, and the site of HMGAl binding to the cyclin Dl promoter within the region of $-1,752$ to $-1,622 \mathrm{nt}$ was uncovered for the first time, at least to the best of our knowledge. Collectively, these results suggest that $I L$ - 17 -induced A549 cell proliferation is linked with HMGAl boosting cyclin Dl gene transcription and expression, indicating that the activation of the HMGAl/cyclin DI axis is indispensable in the mechanisms of NSCLC A549 cell proliferation upon IL-17 stimulation.

In conclusion, the present study verified that the expression level of $I L-17, I L-17 R, H M G A I$ and cyclin $D I$ was significantly increased in samples from patients with NSCLC. Moreover, IL-17R, HMGAl and cyclin DI were positively associated with the malignancy grade of NSCLC. Besides, we revealed that $I L-17$ stimulation prominently upregulated the expression of $H M G A 1$ and cyclin Dl in the A549 cells, and induced cell proliferation in vitro. Furthermore, elevated $H M G A l$ expression directly binds to its response element on the cyclin DI gene promoter, resulting in cyclin $D 1$ gene transcription and expression, and finally promoting A549 cell proliferation (Fig. 6). Overall, our data suggest that the $I L-17 / H M G A 1 /$ cyclin $D I$ axis promotes NSCLC cell proliferation, and may provide new insight into the pathogenesis of NSCLC.

\section{Acknowledgements}

The authors would like to thank Miss Samjhana Pandey for modifying the language.

\section{Funding}

This study was supported by grants from the National Natural Science Foundations of China (nos. 81272532, 81472626 and 81672896).

\section{Availability of data and materials}

The analyzed datasets generated during the study are available from the corresponding author on reasonable request.

\section{Authors' contributions}

YS and WQ designed the study and CZ wrote the manuscript. $\mathrm{CZ}$ and YL carried out experiments. WZ collected and provided the samples of NSCLC patients. DZ, PM, LM and FY participated in the experiments and analyzed the data. YS and YW supervised the study. All authors have read and approved the final manuscript.

\section{Ethics approval and consent to participate}

This study was approved by the Ethics Committee of Nanjing Medical University and conformed to the guidelines outlined by the Declaration of Helsinki. Informed consent was obtained from all patients participating in this research prior to the experiment.

\section{Consent for publication}

Not applicable.

\section{Competing interests}

The authors declare that they have no competing interests.

\section{References}

1. Oh IJ and Ahn SJ: Multidisciplinary team approach for the management of patients with locally advanced non-small cell lung cancer: Searching the evidence to guide the decision. Radiat Oncol J 35: 16-24, 2017

2. McGranahan T and Nagpal S: A Neuro-oncologist's perspective on management of brain metastases in patients with EGFR mutant non-small cell lung cancer. Curr Treat Options Oncol 18: 22, 2017.

3. Zhu HX, Shi L, Zhang Y, Zhu YC, Bai CX, Wang XD and Zhou JB: Myocyte enhancer factor 2D provides a cross-talk between chronic inflammation and lung cancer. J Transl Med 15: 65, 2017.

4. Wu F, Xu J, Huang Q, Han J, Duan L, Fan J, Lv Z, Guo M, Hu G, Chen L, et al: The role of interleukin-17 in lung cancer. Mediators Inflamm 2016: 8494079, 2016.

5. Kwiecien I, Stelmaszczyk-Emmel A, Polubiec-Kownacka M, Dziedzic D and Domagala-Kulawik J: Elevated regulatory T cells, surface and intracellular CTLA-4 expression and interleukin-17 in the lung cancer microenvironment in humans. Cancer Immunol Immunother 66: 161-170, 2017. 
6. Chang SH, Mirabolfathinejad SG, Katta H, Cumpian AM, Gong L, Caetano MS, Moghaddam SJ and Dong C: T helper 17 cells play a critical pathogenic role in lung cancer. Proc Natl Acad Sci USA 111: 5664-5669, 2014.

7. Wei L, Wang H, Yang F, Ding Q and Zhao J: Interleukin-17 potently increases non-small cell lung cancer growth. Mol Med Rep 13: 1673-1680, 2016.

8. Kuwabara T, Ishikawa F, Kondo $\mathrm{M}$ and Kakiuchi T: The role of IL-17 and related cytokines in inflammatory autoimmune diseases. Mediators Inflamm 2017: 3908061, 2017

9. Huang Q, Du J, Fan J, Lv Z, Qian X, Zhang X, Han J, Chen C, $\mathrm{Wu} F$ and Jin Y: The effect of proinflammatory cytokines on IL-17RA expression in NSCLC. Med Oncol 31: 144, 2014.

10. Cheng S, Shao Z, Liu X, Guo L, Zhang X, Na Q, Chen X, Ma Y, Zheng J, Song B, et al: Interleukin 17A polymorphism elevates gene expression and is associated with increased risk of nonsmall cell lung cancer. DNA Cell Biol 34: 63-68, 2015

11. Cao Y, Zhao D, Li P, Wang L, Qiao B, Qin X, Li L and Wang Y: MicroRNA-181a-5p impedes IL-17-induced nonsmall cell lung cancer proliferation and migration through targeting VCAM-1. Cell Physiol Biochem 42: 346-356, 2017.

12. Li Q, Han Y, Fei G, Guo Z, Ren T and Liu Z: IL-17 promoted metastasis of non-small-cell lung cancer cells. Immunol Lett 148: 144-150, 2012

13. Kirshberg S, Izhar U, Amir G, Demma J, Vernea F, Beider K Shlomai Z, Wald H, Zamir G, Shapira OM, et al: Involvement of CCR6/CCL20/IL-17 axis in NSCLC disease progression. PLoS One 6: e24856, 2011.

14. Pan B, Shen J, Cao J, Zhou Y, Shang L, Jin S, Cao S, Che D, Liu F and Yu Y: Interleukin-17 promotes angiogenesis by stimulating VEGF production of cancer cells via the STAT3/GIV signaling pathway in non-small-cell lung cancer. Sci Rep 5: 16053, 2015.

15. Wu L, Chen X, Zhao J, Martin B, Zepp JA, Ko JS, Gu C, Cai G, Ouyang W, Sen G, et al: A novel IL-17 signaling pathway controlling keratinocyte proliferation and tumorigenesis via the TRAF4-ERK5 axis. J Exp Med 212: 1571-1587, 2015.

16. Qiu W, Zhang Y, Liu X, Zhou J, Li Y, Zhou Y, Shan K, Xia M Che N, Feng X, et al: Sublytic C5b-9 complexes induce proliferative changes of glomerular mesangial cells in rat Thynephritis through TRAF6-mediated PI3K-dependent Akt1 activation. J Pathol 226: 619-632, 2012.

17. Gu K, Li MM, Shen J, Liu F, Cao JY, Jin S and Yu Y: Interleukin-17induced EMT promotes lung cancer cell migration and invasion via NF- $\kappa B / Z E B 1$ signal pathway. Am J Cancer Res 5: 1169-1179, 2015.

18. Sumter TF, Xian L, Huso T, Koo M, Chang YT, Almasri TN, Chia L, Inglis C, Reid D and Resar LM: The high mobility group A1 (HMGA1) transcriptome in cancer and development. Curr Mol Med 16: 353-393, 2016.

19. Esposito F, De Martino M, D'Angelo D, Mussnich P, Raverot G Jaffrain-Rea ML, Fraggetta F, Trouillas J and Fusco A: HMGA1pseudogene expression is induced in human pituitary tumors Cell Cycle 14: 1471-1475, 2015.

20. Lin Y, Chen H, Hu Z, Mao Y, Xu X, Zhu Y, Xu X, Wu J, Li S, Mao Q, et al: miR-26a inhibits proliferation and motility in bladder cancer by targeting HMGA1. FEBS Lett 587: 2467-2473, 2013.

21. Zhong J, Liu C, Zhang QH, Chen L, Shen YY, Chen YJ, Zeng X, $\mathrm{Zu}$ XY and Cao RX: TGF- $\beta 1$ induces HMGA1 expression: The role of HMGA1 in thyroid cancer proliferation and invasion. Int J Oncol 50: 1567-1578, 2017.

22. Sekimoto N, Suzuki A, Suzuki Y and Sugano S: Expression of miR-26a exhibits a negative correlation with HMGA1 and regulates cancer progression by targeting HMGA1 in lung adenocarcinoma cells. Mol Med Rep 15: 534-542, 2017.

23. Sarhadi VK, Wikman H, Salmenkivi K, Kuosma E, Sioris T, Salo J, Karjalainen A, Knuutila S and Anttila S: Increased expression of high mobility group A proteins in lung cancer J Pathol 209: 206-212, 2006

24. Zhang Z, Wang Q, Chen F and Liu J: Elevated expression of HMGA1 correlates with the malignant status and prognosis of non-small cell lung cancer. Tumour Biol 36: 1213-1219, 2015.

25. Musgrove EA, Caldon CE, Barraclough J, Stone A and Sutherland RL: Cyclin D as a therapeutic target in cancer. Nat Rev Cancer 11: 558-572, 2011

26. Qie S and Diehl JA: Cyclin D1, cancer progression, and opportunities in cancer treatment. J Mol Med (Berl) 94: 1313-1326, 2016.

27. Tian XP, Jin XH, Li M, Huang WJ, Xie D and Zhang JX: The depletion of PinX1 involved in the tumorigenesis of non-small cell lung cancer promotes cell proliferation via p15/cyclin D1 pathway. Mol Cancer 16: 74, 2017.
28. Shan K, Pang R, Zhao C, Liu X, Gao W, Zhang J, Zhao D, Wang Y and Qiu W: IL-17-triggered downregulation of miR-497 results in high HIF-1 $\alpha$ expression and consequent IL-1 $\beta$ and IL-6 production by astrocytes in EAE mice. Cell Mol Immunol 14: $1-15,2017$.

29. Qiu W, Zhou J, Zhu G, Zhao D, He F, Zhang J, Lu Y, Yu T, Liu L and Wang Y: Sublytic C5b-9 triggers glomerular mesangial cell apoptosis via XAF1 gene activation mediated by p300-dependent IRF-1 acetylation. Cell Death Dis 5: e1176, 2014.

30. Livak KJ and Schmittgen TD: Analysis of relative gene expression data using real-time quantitative PCR and the $2(-\Delta \Delta$ C(T)) Method. Methods 25: 402-408, 2001.

31. Al-Azhri J, Zhang Y, Bshara W, Zirpoli G, McCann SE Khoury T, Morrison CD, Edge SB, Ambrosone CB and Yao S: Tumor expression of Vitamin D receptor and breast cancer histopathological characteristics and prognosis. Clin Cancer Res 23: 97-103, 2017.

32. Surowiak P, Materna V, Györffy B, Matkowski R, Wojnar A, Maciejczyk A, Paluchowski P, Dziegiel P, Pudełko M, Kornafel J, et al: Multivariate analysis of oestrogen receptor alpha, pS2, metallothionein and CD24 expression in invasive breast cancers. Br J Cancer 95: 339-346, 2006

33. Zhang J, Li Y, Shan K, Wang L, Qiu W, Lu Y, Zhao D, Zhu G, He F and Wang Y: Sublytic C5b-9 induces IL-6 and TGF- $\beta 1$ production by glomerular mesangial cells in rat Thy-1 nephritis through p300-mediated C/EBP $\beta$ acetylation. FASEB J 28 1511-1525, 2014.

34. He F, Zhou M, Yu T, Zhao D, Zhang J, Qiu W, Lu Y, Liu Y, Wang L and Wang Y: Sublytic C5b-9 triggers glomerular mesangial cell apoptosis in rat Thy-1 nephritis via Gadd45 activation mediated by Egr-1 and p300-dependent ATF3 acetylation. J Mol Cell Biol 8: 477-491, 2016.

35. Dement GA, Treff NR, Magnuson NS, Franceschi V and Reeves R: Dynamic mitochondrial localization of nuclear transcription factor HMGA1. Exp Cell Res 307: 388-401, 2005.

36. Kolb S, Fritsch R, Saur D, Reichert M, Schmid RM and Schneider G: HMGA1 controls transcription of insulin receptor to regulate cyclin D1 translation in pancreatic cancer cells. Cancer Res 67: 4679-4686, 2007.

37. Vendramini-Costa DB and Carvalho JE: Molecular link mechanisms between inflammation and cancer. Curr Pharm Des 18 : 3831-3852, 2012.

38. Lee JJ, Kim HJ, Yang CS, Kyeong HH, Choi JM, Hwang DE, Yuk JM, Park K, Kim YJ, Lee SG, et al: A high-affinity protein binder that blocks the IL-6/STAT3 signaling pathway effectively suppresses non-small cell lung cancer. Mol Ther 22: 1254-1265, 2014.

39. Pan B, Che D, Cao J, Shen J, Jin S, Zhou Y, Liu F, Gu K, Man Y, Shang L, et al: Interleukin-17 levels correlate with poor prognosis and vascular endothelial growth factor concentration in the serum of patients with non-small cell lung cancer. Biomarkers 20: 232-239, 2015.

40. Quintavalle C, Burmeister K, Piscuoglio S, Quagliata L, Karamitopoulou E, Sepe R, Fusco A, Terracciano LM, Andersen JB, Pallante $\mathrm{P}$, et al: High mobility group A1 enhances tumorigenicity of human cholangiocarcinoma and confers resistance to therapy. Mol Carcinog 56: 2146-2157, 2017.

41. Ahlin C, Lundgren C, Embretsén-Varro E, Jirström K, Blomqvist $\mathrm{C}$ and Fjällskog M: High expression of cyclin D1 is associated to high proliferation rate and increased risk of mortality in women with ER-positive but not in ER-negative breast cancers. Breast Cancer Res Treat 164: 667-678, 2017.

42. Huso TH and Resar LM: The high mobility group A1 molecular switch: Turning on cancer - can we turn it off? Expert Opin Ther Targets 18: 541-553, 2014

43. Li Z, Qu L, Luo W, Tian Y, Zhai H, Xu K and Zhong H: Mig-6 is down-regulated in HCC and inhibits the proliferation of HCC cells via the P-ERK/Cyclin D1 pathway. Exp Mol Pathol 102: 492-499, 2017.

44. Hyun YS, Han DS, Lee AR, Eun CS, Youn J and Kim HY Role of IL-17A in the development of colitis-associated cancer. Carcinogenesis 33: 931-936, 2012.

45. Fabre T, Kared H, Friedman SL and Shoukry NH: IL-17A enhances the expression of profibrotic genes through upregulation of the TGF- $\beta$ receptor on hepatic stellate cells in a JNK-dependent manner. J Immunol 193: 3925-3933, 2014.

46. Hommura F, Katabami M, Leaner VD, Donninger H, Sumter TF, Resar LM and Birrer MJ: HMG-I/Y is a c-Jun/activator protein-1 target gene and is necessary for c-Jun-induced anchorage-independent growth in Rat1a cells. Mol Cancer Res 2: 305-314, 2004. 
47. Zhou WB, Zhong CN, Luo XP, Zhang YY, Zhang GY, Zhou DX and Liu LP: miR-625 suppresses cell proliferation and migration by targeting HMGA1 in breast cancer. Biochem Biophys Res Commun 470: 838-844, 2016.

48. Liu Y, Wang Y, Zhang Y, Fu J and Zhang G: Knockdown of HMGA1 expression by short/small hairpin RNA inhibits growth of ovarian carcinoma cells. Biotechnol Appl Biochem 59: 1-5, 2012.

49. Yang Q, Wang X, Tang C, Chen X and He J: H19 promotes the migration and invasion of colon cancer by sponging miR-138 to upregulate the expression of HMGA1. Int J Oncol 50: 1801-1809, 2017.
50. Żuryń A, Litwiniec A, Safiejko-Mroczka B, KlimaszewskaWiśniewska A, Gagat M, Krajewski A, Gackowska L and Grzanka D: The effect of sulforaphane on the cell cycle, apoptosis and expression of cyclin D1 and p21 in the A549 non-small cell lung cancer cell line. Int J Oncol 48: 2521-2533, 2016.

51. Otto T and Sicinski P: Cell cycle proteins as promising targets in cancer therapy. Nat Rev Cancer 17: 93-115, 2017.

52. Chikara S, Lindsey K, Dhillon H, Mamidi S, Kittilson J, Christofidou-Solomidou M and Reindl KM: Enterolactone induces G1-phase cell cycle arrest in nonsmall cell lung cancer cells by downregulating cyclins and cyclin-dependent kinases. Nutr Cancer 69: 652-662, 2017. 